\title{
A single dose of SAAVI MVA-C reboosts rhesus macaques after more than 3 years post DNA-MVA prime-boost vaccination
}

\author{
GK Chege*, W Burgers, T Muller, EG Shephard, C Williamson, A Williamson \\ From AIDS Vaccine 2012 \\ Boston, MA, USA. 9-12 September 2012
}

\section{Background}

We have previously reported induction of robust immune responses in rhesus macaques following a prime boost immunization with candidate $\mathrm{HIV}-1$ vaccines, SAAVI DNA-C (DNA) and SAAVI MVA-C (MVA). These vaccines are already in clinical evaluation. In the current study, we investigated whether re-boosting these animals with a single MVA inoculation after more than 3 years was sufficient to restore previous magnitudes of HIVspecific immune responses.

\section{Methods}

Seven rhesus macaques which had been vaccinated with three doses of DNA vaccine (4mg DNA/dose) and two doses of MVA ( $10^{9} \mathrm{pfu}$ MVA/dose) in a past study, $>3$ years previously, were re-boosted with a single dose of MVA. HIV-1-specific responses were quantified in the peripheral blood using an IFN-gamma ELISPOT assay.

\section{Results}

A peak magnitude of response (1146 $\left.\pm 240 \mathrm{sfu} / 10^{6} \mathrm{PBMC}\right)$ was reached 1 week after vaccination with the first dose of MVA. The second MVA inoculation did not increase these responses which declined to undetectable levels by 1 year post vaccination. After re-boosting with MVA after 3.5 years post the second MVA, all animals responded, with a peak response $\left(1824 \pm 672 \mathrm{sfu} / 10^{6}\right.$ PBMC) being reached 1 week after vaccination. Although the mean magnitude of the second peak was not significantly higher than the one seen in the first peak, boosting of responses in 3 of 7 animals with an apparent broadening of the breadth of responses was observed.

University of Cape Town, Cape Town, South Africa

\section{Conclusion}

These preliminary data suggest a long-term preservation of vaccine memory following a prime-boost vaccination regimen with SAAVI DNA-C and SAAVI MVA-C vaccines.

Published: 13 September 2012

doi:10.1186/1742-4690-9-S2-P32

Cite this article as: Chege et al:: A single dose of SAAVI MVA-C reboosts rhesus macaques after more than 3 years post DNA-MVA prime-boost vaccination. Retrovirology 2012 9(Suppl 2):P32.
Submit your next manuscript to BioMed Central and take full advantage of:

- Convenient online submission

- Thorough peer review

- No space constraints or color figure charges

- Immediate publication on acceptance

- Inclusion in PubMed, CAS, Scopus and Google Scholar

- Research which is freely available for redistribution
C Biomed Central 